Lana Nastić ${ }^{1}$

Marko Jeločnik ${ }^{2}$

Jonel Subić ${ }^{3}$

Institute of Agricultural Economics, Belgrade, Serbia
ORIGINAL SCIENTIFIC ARTICLE doi:10.5937/ekonomika1804069N

Received: November, 03, 2018

Accepted: December, 06, 2018

\title{
CONTRIBUTION MARGIN IN SILAGE MAZE PRODUCTION ${ }^{4}$
}

\begin{abstract}
Silage maize as a fodder crop has been still produced in Republic of Serbia at insufficient surfaces, mostly at holdings focused to livestock production, providing on that way adequate volume of quality animal feed. In order to determine economic effects of production in paper is used analytical calculation based on variable costs, as well as method of critical values of production and sensitive analysis. Analysis covers three year period, involving comparison of gained results. Paper goal is to present the results achieved in mentioned production, as to evaluate the importance of yields height to gained contribution margin (positive contribution margin was determined within the complete period).
\end{abstract}

Key words: silage maize production, contribution margin, variable costs, Serbia.

JEL classification: $Q 1, Q 120$

\section{МАРЖА ПОКРИЋА У ПРОИЗВОДЫИ СИЛАЖНОГ КУКУРУЗА}

\begin{abstract}
Апстракт
Кукуруз за силажу се зарад исхране стоке у Републици Србији још увек производи на недовољним површинама и то у већини случајева на газдинствима усмереним и на сточарску производюу, која на овај начин обезбеђују довољне количине квалитетне сточне хране. Да би се утврдили економски ефекти производње у раду је коришћена аналитичка калкулачија на бази варијабилних трошкова, као и метод критичних вредности и метод сензитивне анализе. Анализа је вршена за временски период од три године, а накнадно је извршена и компарација остварених резултата. Циљ рада је да се прикажу резултати који се остварују у овој линији ратарске производюе и утврди значај висине приноса

\footnotetext{
${ }^{1}$ lana_n@iep.bg.ac.rs

${ }^{2}$ marko_j@iep.bg.ac.rs

3jonel_s@iep.bg.ac.rs

${ }^{4}$ Acknowledgements - Paper is a part of research at the project no. III 46006 - Sustainable agriculture and rural development in terms of the Republic of Serbia strategic goals realization within the Danube region, financed by the Ministry of Education, Science and Technological Development of the Republic of Serbia.
} 
на финансијски резултат производње (позитивна маржа покрића је остварена током читавог посматраног периода).

Кључне речи: производња силажног кукуруза, маржа покрића, варијабилни трошкови, Србија.

\section{Introduction}

Maize has great economic importance as it is used for feeding cattle, in human nutrition and as input for production of large number of industrial products. It provides gaining of over 1,500 industrial products, primarily food products, pharmaceuticals, animal food products, cosmetic products, raw materials for further processing, etc. (Munćan, Živković, 2014).

The most of territory of Serbia has moderate continental climate (Sekulić et al., 2012), suitable for crop production. Unfortunately, in last decades national agriculture is facing with general deficit of rainfalls followed by high temperatures and much frequent and longer heat waves, that induce presence of high intensity droughts (Gulan, 2012). Besides, less than 3\% of arable land is irrigated (RPKNS, 2017)

Traditionally, maize is the most grown crop in the Republic of Serbia. At national level, the largest areas under the maize are directed to grain production, while its production as silage maize is conducted at much smaller areas. So for animal feeding, grain is generally more used than silage. In 2017, under the grain maize there were $1,002,319$ ha with total production of 4,018,370 tons and average yield of around 4.0 tons per hectare. On the other side, in same year silage maize was grown at 33,244 hectares (Table 1.).

Table 1: Areas, total production and average yield per hectare of silage maize in the Republic of Serbia

\begin{tabular}{|c|rr|r|r|}
\hline Year & \multicolumn{2}{|c|}{$\begin{array}{c}\text { Harvested areas } \\
\text { (in ha) }\end{array}$} & $\begin{array}{c}\text { Total production } \\
\text { (in t) }\end{array}$ & $\begin{array}{c}\text { Average yield } \\
\text { (t/ha) }\end{array}$ \\
\hline 2008. & 25,318 & 459,310 & 18.1 \\
\hline 2009. & 26,758 & 586,919 & 21.9 \\
\hline 2010. & 27,503 & 657,201 & 22.9 \\
\hline 201. & 30,157 & 655,618 & 21.1 \\
\hline 2012. & 47,927 & 736,943 & 14.9 \\
\hline 2013. & 32,418 & 693,258 & 20.7 \\
\hline 2014. & 32,143 & 617,447 & 19.2 \\
\hline 2015. & 34,046 & 589,166 & 17.3 \\
\hline 2016. & 30,524 & 650,741 & 21.3 \\
\hline 2017. & 33,244 & 534,521 & 16.1 \\
\hline
\end{tabular}

Source: SORS, 2018. 
The average yield of silage maize in Serbia is generally at low level and during the period 2008-2017 it ranged from 14.9 to 22.9 t/ha. The lowest yield was achieved in 2012 that was characterized by extreme drought. Last decades, as the consequence of global warming, it came to certain changes in climate, where the hot issue become the lack and bad distribution of rainfalls during the vegetation period. Šmunic and associates (2007) were analysed the needs of several crops for water within the region, as well as the problems related to their irrigation. Among observed crops was silage maize too. Some conclusion goes in a way that silage corn shows the highest deficit for water during the July.

As state Živić and associates (2016) in Serbia in areas where maize is grown in average is missing up to $200 \mathrm{~mm}$ of rainfalls. Lack of water has unfavourable impact both to the development of plants and achieved yields. Possibility of appliance of agrotechnical measure of irrigation in maize is also observed by Jeločnik (2017).

"In line to genetic potential and available agro ecological conditions of production, yield of silage maize ranges 12-25 tons of total dry matter per hectare within the phase of physiological maturity for silaging with the dry matter content of 35-42\%" (Terzić et al., 2012).

During the selection of silage maize hybrids, it is necessary to know the quality parameters important for later gaining of maize silage, such are "the yield of dry matter from complete plant, the share of cobs in dry matter, content of fibres in acid and neutral detergent, as in vitro digestibility" (Radosavljević et al., 2005).

According to analysis of production costs in crop production in Vojvodina and their comparison in various years it was concluded that agrarian policy should enable stabile business conditions, as unstable economic conditions have negative impacts to primary agricultural production, as in such a this environment producers cannot make a proper business decisions (Bošnjak, Rodić, 2010).

Economic effects of production of various crops or production of one crop by different production intensity could be compared according to analytical calculation based on variable costs (Ivanović, Jeločnik, 2016; Jeločnik et al., 2013).

Production of silage maize in Serbia is mostly organized by those producers that are focused to livestock production. They usually use the silage of whole plant for cattle feeding. In addition to concentrated feed, silage maize represents significant feed in livestock production at ruminants. In this way, heads are approaching to more quality feed in order to achieve better production results. But, as states Orović (2017) advancements in the area of agricultural production that happened in last 10-20 years, are still insufficient for greater progress, so it should continue with activities on racial composition of domestic animals, conditions of their breeding and care, adequate nutrition, improvement in crop, fodder and fruit plants growing, etc.

\section{Methodology and data sources}

Research was based on data gained from family agricultural holdings oriented to crop and livestock production, located in Mačva District. Whole production of silage maize (silage of complete plant) is used in animal nutrition at the holdings. Data are collected for three production years (period 2015-2017). Main research goal 
is presentation of economic effects in silage maize production, as well as yields and variable costs impact on the height of contribution margin. Besides gained producers data, secondary data of national Statistical Office, scientific and professional literature focused on research theme was also used. Better analysis is provided by presentation of all results with tables, expressed in RSD and EUR per ha of production surfaces.

Calculation of contribution margin in production of certain crop culture considers the totally gained incomes by the production of certain culture subtracted for totally generated variable costs (Subić, Jeločnik, 2016). Generally, variable cost in crop production involves: seeds, fertilizers, pesticides, fuels and lubricants or external services of mechanization, engaged labour, etc. (Subić et al., 2010).

According to significant impact of yield and price oscillation of products and main inputs on gained financial results, there are justified requirements for analysis of production results in conditions of uncertainty. Most common method for that purpose is determination of critical production values (equalizing of contribution margin to zero): critical price, critical yield and critical variable costs. In same manner it will be used the method of sensitivity analysis, which follows the trend of change in contribution margin due to decrease in yield or sales price, or due to growth of variable costs of production (Nastić et al., 2014).

\section{Results with discussion}

Calculation of silage maize production was made according to data collected from the production of maize hybrid AS 72, used for silage preparation from the whole plant. Mentioned hybrid is also used for the grain production, but in case it is used for the production of silage, larger volume of seed per unit of production area (for 10\%) is sown. Research considers only one maize hybrid in order to eliminate the impact of different varieties on the amount of gained incomes and incurred costs. In next tables (Table 2., 3. and 4.) are presented calculations based on variable costs in silage maize production. Within the analysed period the highest incomes were generated in 2016., mostly initiated by the volume of achieved yields of $45.000 \mathrm{~kg} / \mathrm{ha}$.

Table 2: Calculation of silage maize production in 2015.

\begin{tabular}{|c|c|c|c|c|c|}
\hline Element & Quantity & UM & $\begin{array}{c}\text { Price (RSD)/ } \\
\text { UM }\end{array}$ & Total RSD/ha & $\begin{array}{c}\text { Total EUR/ } \\
\text { ha } \\
\end{array}$ \\
\hline \multicolumn{6}{|l|}{ A. Incomes } \\
\hline Silage maize & $35.000,00$ & $\mathrm{~kg}$ & 5,00 & $175.000,00$ & $1.449,52$ \\
\hline Subsidies & & & & $12.000,00$ & 99,40 \\
\hline \multicolumn{4}{|l|}{ Value of production (total A) } & $187.000,00$ & $1.548,91$ \\
\hline \multicolumn{6}{|l|}{ B. Variable costs } \\
\hline Seed & 2,50 & $\mathrm{~kg}$ & $4.000,00$ & $10.000,00$ & 82,83 \\
\hline Mineral fertilizers & & & & $28.800,00$ & 238,55 \\
\hline Pesticides & & & & $2.100,00$ & 17,39 \\
\hline Costs of mechanization & & & & $31.600,00$ & 261,74 \\
\hline Other costs & & & & 650,00 & 5,38 \\
\hline \multicolumn{4}{|l|}{ Variable costs (total B) } & $73.150,00$ & 605,90 \\
\hline \multicolumn{4}{|l|}{ C. Contribution margin (A-B) } & $113.850,00$ & 943,01 \\
\hline
\end{tabular}


Besides the production value, in generation of total income the public subsidies for plant production provided by the Ministry of Agriculture has been also participated. This sum in mentioned period had decreasing trend, from $12.000 \mathrm{RSD} / \mathrm{ha}$ in 2015 ., to 4.000 $\mathrm{RSD} / \mathrm{ha}$ in 2016., or $2.000 \mathrm{RSD} / \mathrm{ha}$ in 2017. (MPŠV, 2016).

Table 3: Calculation of silage maize production in 2016.

\begin{tabular}{|c|c|c|c|c|c|}
\hline Element & Quantity & UM & $\begin{array}{c}\text { Price (RSD)/ } \\
\text { UM }\end{array}$ & $\begin{array}{c}\text { Total RSD/ } \\
\text { ha }\end{array}$ & $\begin{array}{c}\text { Total } \\
\text { EUR/ha }\end{array}$ \\
\hline \multicolumn{6}{|l|}{ A. Incomes } \\
\hline Silage maize & 45000,00 & $\mathrm{~kg}$ & 5,00 & $225.000,00$ & $1.827,49$ \\
\hline Subsidies & & & & $4.000,00$ & 32,49 \\
\hline \multicolumn{4}{|c|}{ Value of production (total A) } & $229.000,00$ & $1.859,97$ \\
\hline \multicolumn{6}{|c|}{ B. Variable costs } \\
\hline Seed & 2,50 & $\mathrm{~kg}$ & $4.150,00$ & $10.375,00$ & 84,27 \\
\hline Mineral fertilizers & & & & $29.400,00$ & 238,79 \\
\hline Pesticides & & & & $3.100,00$ & 25,18 \\
\hline Costs of mechanization & & & & $31.220,00$ & 253,57 \\
\hline Other costs & & & & 720,00 & 5,85 \\
\hline \multicolumn{4}{|c|}{ Variable costs (total B) } & $74.815,00$ & 607,66 \\
\hline \multicolumn{4}{|c|}{ C. Contribution margin (A-B) } & $154.185,00$ & $1.252,31$ \\
\hline
\end{tabular}

Within the observed period, the highest contribution margin was gained in 2016., in amount of 154.185,00 RSD/ha, or 1.252,31 EUR/ha. In both other years, the value of contribution margin is at almost the same level, approximately around 950,00 EUR/ha. On the level of the contribution margin, or its change in observed period, the greatest impact had the achieved yield of grown crop, that was the highest in 2016. Such results are primarily caused by the weather conditions appeared in analysed period, as there were no significant changes in the applied agro-technical measures.

Table 4: Calculation of silage maize production in 2017.

\begin{tabular}{|c|c|c|c|c|c|}
\hline Element & Quantity & UM & $\begin{array}{c}\text { Price (RSD)/ } \\
\text { UM }\end{array}$ & $\begin{array}{c}\text { Total RSD/ } \\
\text { ha }\end{array}$ & $\begin{array}{c}\text { Total EUR/ } \\
\text { ha }\end{array}$ \\
\hline \multicolumn{6}{|l|}{ A. Incomes } \\
\hline Silage maize & $35.000,00$ & $\mathrm{~kg}$ & 5,00 & $175.000,00$ & $1.442,23$ \\
\hline Subsidies & & & & $2.000,00$ & 16,48 \\
\hline \multicolumn{4}{|c|}{ Value of production (total A) } & $177.000,00$ & $1.458,71$ \\
\hline \multicolumn{6}{|l|}{ B. Variable costs } \\
\hline Seed & 2,50 & $\mathrm{~kg}$ & $3.800,00$ & $9.500,00$ & 78,29 \\
\hline Mineral fertilizers & & & & $9.600,00$ & 79,12 \\
\hline Pesticides & & & & $4.350,00$ & 35,85 \\
\hline Costs of mechanization & & & & $38.100,00$ & 313,99 \\
\hline Other costs & & & & 720,00 & 5,93 \\
\hline \multicolumn{4}{|l|}{ Variable costs (total B) } & $62.270,00$ & 513,19 \\
\hline \multicolumn{4}{|c|}{ C. Contribution margin (A-B) } & $114.730,00$ & 945,52 \\
\hline
\end{tabular}


Within the structure of variable costs the highest share has mechanization costs. In all years their share is above $40 \%$, and the highest is in 2017 (61,18\% of total variable costs).

The costs of mineral fertilizers and pesticides are shown in Table 5.

Table 5: Costs of mineral fertilizers and pesticides

\begin{tabular}{|c|c|c|c|c|c|}
\hline Element & Quantity & UM & Price (RSD)/UM & Total RSD/ha & Total EUR/ha \\
\hline \multicolumn{6}{|c|}{2015.} \\
\hline \multicolumn{4}{|c|}{ Mineral fertilizers (total) } & $28.800,00$ & 238,55 \\
\hline NPK $(15: 15: 15)$ & 300,00 & $\mathrm{~kg}$ & 48,00 & $14.400,00$ & 119,27 \\
\hline $\mathrm{KAN}$ & 400,00 & $\mathrm{~kg}$ & 36,00 & $14.400,00$ & 119,27 \\
\hline \multicolumn{4}{|l|}{ Pesticides (total) } & $2.100,00$ & 17,39 \\
\hline Motivel & 1,00 & 1 & $2.100,00$ & $2.100,00$ & 17,39 \\
\hline \multicolumn{6}{|c|}{2016.} \\
\hline \multicolumn{4}{|c|}{ Mineral fertilizers (total) } & $29.400,00$ & 238,79 \\
\hline NPK $(15: 15: 15)$ & 300,00 & $\mathrm{~kg}$ & 50,00 & $15.000,00$ & 121,83 \\
\hline KAN & 400,00 & $\mathrm{~kg}$ & 36,00 & $14.400,00$ & 116,96 \\
\hline \multicolumn{4}{|l|}{ Pesticides (total) } & $3.100,00$ & 25,18 \\
\hline Siran & 2,0000 & $\mathrm{~kg}$ & 850,00 & $1.700,00$ & 13,81 \\
\hline Rezon & 2,0000 & 1 & 700,00 & $1.400,00$ & 11,37 \\
\hline \multicolumn{6}{|c|}{2017.} \\
\hline \multicolumn{4}{|c|}{ Mineral fertilizers (total) } & $9.600,00$ & 79,12 \\
\hline KAN & 300,00 & $\mathrm{~kg}$ & 32,00 & $9.600,00$ & 79,12 \\
\hline \multicolumn{4}{|l|}{ Pesticides (total) } & $4.350,00$ & 35,85 \\
\hline Basar & 1,50 & $\mathrm{~kg}$ & $2.000,00$ & $3.000,00$ & 24,72 \\
\hline Rezon & 1,50 & 1 & 900,00 & $1.350,00$ & 11,13 \\
\hline
\end{tabular}

Besides the cost of mechanization, significant share in total variable costs of silage maize production have the costs of mineral fertilizers, that ranges from $15,42 \%$ (in 2017 ., when only KAN was used) to $39,37 \%$ (in 2015.).

Besides height of yields, for animal nutrition its content is also important, as needs of domestic animals could be properly satisfied. Influence of fertilization to silage maize are observed by Manojlović and Marijanušić (2016). They conclude that during each vegetation according to fact that silage maize produce high volume of biomass rich with mineral elements, production requires increased quantity of various minerals (macro and micro elements) that are injected into the land by appliance of certain mineral fertilizers.

Costs of pesticides have not differ significantly, as in terms of used preparations, as in terms of their total value (from 17,39 to $35,85 \mathrm{EUR} / \mathrm{ha}$ ).

Within the structure of the costs of machine operations (Table 6.), the most significant are silage preparation (from $37,65 \%$ to $47,24 \%$ ) and transport (from 23,88 to $29,15 \%$ ).

It is important to note that besides mentioned costs, it has been also added costs of transportation, preparation of silage (wading) and purchase of bacterial inoculants often used in practice. Costs of transport and wading are not indicated because their amount oscillates according to distance between the parcel and silo, type and capacity of aggregate used for transport, type of silo, quality of mass used for silage, etc. 
Table 6: Costs of mechanization

\begin{tabular}{|c|c|c|c|c|c|c|}
\hline \multirow{3}{*}{ Machine operation $^{1}$} & \multicolumn{6}{|c|}{ Year } \\
\hline & \multicolumn{2}{|c|}{2015.} & \multicolumn{2}{|c|}{2016.} & \multicolumn{2}{|c|}{2017.} \\
\hline & RSD/ha & EUR/ha & RSD/ha & EUR/ha & RSD/ha & EUR/ha \\
\hline Tillage & $9.000,00$ & 74,55 & $9.100,00$ & 73,91 & $9.100,00$ & 75,00 \\
\hline $\begin{array}{l}\text { Transport of mineral } \\
\text { fertilizers }\end{array}$ & $1.400,00$ & 11,60 & 750,00 & 6,09 & $1.500,00$ & 12,36 \\
\hline $\begin{array}{l}\text { Spreading of mineral } \\
\text { fertilizers }\end{array}$ & $1.350,00$ & 11,18 & $1.400,00$ & 11,37 & $1.450,00$ & 11,95 \\
\hline Rototilling & $2.400,00$ & 19,88 & $2.530,00$ & 20,55 & $2.550,00$ & 21,02 \\
\hline Sowing & $1.450,00$ & 12,01 & $1.490,00$ & 12,10 & $1.500,00$ & 12,36 \\
\hline Pesticide spraying & $2.400,00$ & 19,88 & $2.470,00$ & 20,06 & $2.500,00$ & 20,60 \\
\hline Between row cultivation & $1.700,00$ & 14,08 & $1.480,00$ & 12,02 & $1.500,00$ & 12,36 \\
\hline Silage preparation & $11.900,00$ & 98,57 & $12.000,00$ & 97,47 & $18.000,00$ & 148,34 \\
\hline Total & $31.600,00$ & 261,74 & $31.220,00$ & 253,57 & $38.100,00$ & 313,99 \\
\hline
\end{tabular}

Source: author's calculation according to ZSV, 2013.

Note: ${ }^{1}$ As average price of diesel it is assumed the price of $135 \mathrm{RSD} / \mathrm{l}$ in 2015., or 140 $\mathrm{RSD} / 1$ in 2016. and 2017.

Besides contribution margin, critical values of production are also calculated: critical price, critical yield and critical variable costs (Table 7.). Mentioned indicators are prepared for all analysed years. The lowest critical price and the highest critical variable costs are recorded in 2016., while the highest critical price and the lowest variable costs are recorded in 2017.

Table 7: Critical values in silage maize production

\begin{tabular}{|c|c|c|}
\hline Description & RSD(kg)/ha & EUR(kg)/ha \\
\hline \multicolumn{3}{|c|}{2015.} \\
\hline Expected yield (OP) & $35.000,00$ & 289,90 \\
\hline Expected price (OC) & 5,00 & 0,04 \\
\hline Subsidy (p) & $12.000,00$ & 99,40 \\
\hline Variable costs (VT) & $73.150,00$ & 605,90 \\
\hline Critical price: $\mathrm{KC}=(\mathrm{VT}-\mathrm{p}) / \mathrm{OP}$ & 1,75 & 0,01 \\
\hline Critical yield: $K P=(V T-p) / O C$ & $12.230,00$ & 101,30 \\
\hline $\begin{array}{l}\text { Critical variable costs: } \\
\mathrm{KVT}=(\mathrm{OP} \times \mathrm{OC})+\mathrm{p} \\
\end{array}$ & $187.000,00$ & $1.548,91$ \\
\hline \multicolumn{3}{|c|}{2016.} \\
\hline Expected yield (OP) & $45.000,00$ & 365,50 \\
\hline Expected price (OC) & 5,00 & 0,04 \\
\hline Subsidy (p) & $4.000,00$ & 32,49 \\
\hline Variable costs (VT) & $74.815,00$ & 607,66 \\
\hline Critical price: $\mathrm{KC}=(\mathrm{VT}-\mathrm{p}) / \mathrm{OP}$ & 1,57 & 0,01 \\
\hline Critical yield: $K P=(V T-p) / O C$ & $14.163,00$ & 115,03 \\
\hline $\begin{array}{l}\text { Critical variable costs: } \\
\text { KVT }=(O P \times O C)+p\end{array}$ & $229.000,00$ & $1.859,97$ \\
\hline
\end{tabular}


2017.

\begin{tabular}{|l|r|r|}
\hline Expected yield (OP) & $35.000,00$ & 288,45 \\
\hline Expected price (OC) & 5,00 & 0,04 \\
\hline Subsidy (p) & $2.000,00$ & 16,48 \\
\hline Variable costs (VT) & $62.270,00$ & 513,19 \\
\hline Critical price: KC = (VT - p) / OP & 1,72 & 0,01 \\
\hline Critical yield: KP = (VT - p) / OC & $12.054,00$ & 99,34 \\
\hline Critical variable costs: & $177.000,00$ & $1.458,71$ \\
KVT $=(\mathbf{O P} \mathbf{X C})+\mathbf{p}$ & & \\
\hline
\end{tabular}

Achieved yields, or produced quantity of silage maize has significant impact on the value of gained contribution margin. For this reason, it was prepared the sensitive analysis of contribution margin change due to fall in yield or price of final product (Table 8.).

Table 8: Change of contribution margin in silage maize production according to fall of crop yield or price

\begin{tabular}{|c|c|c|}
\hline $\begin{array}{l}\text { Fall of yield or price } \\
\text { of crop }(\%)\end{array}$ & $\begin{array}{l}\text { Change of contribution margin (RSD/ } \\
\text { ha) }\end{array}$ & $\begin{array}{l}\text { Change of contribution margin } \\
\text { (EUR/ha) }\end{array}$ \\
\hline \multicolumn{3}{|c|}{2015} \\
\hline 10,00 & $96.350,00$ & 798,06 \\
\hline 20,00 & $78.850,00$ & 653,11 \\
\hline 30,00 & $61.350,00$ & 508,16 \\
\hline 40,00 & $43.850,00$ & 363,21 \\
\hline 50,00 & $26.350,00$ & 218,26 \\
\hline 60,00 & $8.850,00$ & 73,30 \\
\hline \multicolumn{3}{|c|}{2016.} \\
\hline 10,00 & $131.685,00$ & $1.069,57$ \\
\hline 20,00 & $109.185,00$ & 886,82 \\
\hline 30,00 & $86.685,00$ & 704,07 \\
\hline 40,00 & $64.185,00$ & 521,32 \\
\hline 50,00 & $41.685,00$ & 338,57 \\
\hline 60,00 & $19.185,00$ & 155,82 \\
\hline \multicolumn{3}{|c|}{2017.} \\
\hline 10,00 & $97.230,00$ & 801,30 \\
\hline 20,00 & $79.730,00$ & 657,08 \\
\hline 30,00 & $62.230,00$ & 512,86 \\
\hline 40,00 & $44.730,00$ & 368,63 \\
\hline 50,00 & $27.230,00$ & 224,41 \\
\hline 60,00 & $9.730,00$ & 80,19 \\
\hline
\end{tabular}

Although the height of the contribution margin over the years show pronounced variations, the sensitivity of the contribution margin to the fall of yield or price of product in all analysed years is relatively equalized, the margin equals to zero at yields or price reducing for 65,05 (in 2015.) to $68,52 \%$ (in 2016.). 


\section{Conclusion}

Areas and yields in silage maize production in the Republic of Serbia within the period 2008-2017. have been showed expressed oscillations, where the lowest yield was achieved in 2012. in conditions of extremely dry year. Analysing the production of silage maize in the Mačva Region for the period 2015-2017., there are achieved positive contribution margins. The best result was gained in 2016. (154,185.00 RSD) as the result of achievement of the highest yields in silage maize production (45 tons). In the structure of variable costs, the largest share has the costs of mechanization, whose share in all observed years were over $40 \%$. By the method of sensitive analysis, it was determined that contribution margin is equalling to zero if yield or a price are decreasing for around $65 \%$.

\section{References}

Bošnjak, D. \& Rodić, V. (2010). Komparativna analiza troškova proizvodnje osnovnih ratarskih useva u Vojvodini. Ekonomika poljoprivrede, 57(2), 233-243.

Gulan, B. (2012). Elementarna nepogoda ili nova stvarnost: Suša će prepoloviti prinose. Korak, 12(73), 28-37.

Ivanović, L. \& Jeločnik, M. (2016). Uputstvo i model za izračunavanje marže pokrića na poljoprivrednim gazdinstvima. In Subić, J., Janković, S., Vasiljević, Z. \& Lukić, M. (Eds.), Unapređenje finansijskih znanja i evidencija na poljoprivrednim gazdinstvima u Republici Srbiji (145-160), Beograd, Srbija: Institut za ekonomiku poljoprivrede.

Jeločnik (2017). Ekonomski instrumenti za upravljanje klimatskim rizicima u ratarskoj proizvodnji Republike Srbije. Nepublikovana doktorska disertacija, Novi Sad, Srbija: Poljoprivredni fakultet.

Jeločnik, M., Bekić, B. \& Subić, J. (2013). Marža pokrića u mobilnom pčelarenju na teritoriji grada Pančeva. Ekonomika, 59 (2), 73-82.

Manojlović, M. \& Marijanušić, K. (2016). Uticaj đubrenja na prinos i kvalitet krme lucerke i krmnog kukuruza. Letopis naučnih radova, 40 (1), 28-39.

MPŠV (2016). Pravilnik o načinu ostvarivanja prava na osnovne podsticaje u biljnoj proizvodnji i obrascu zahteva za ostvarivanje tih podsticaja. Službeni glasnik Republike Srbije, br. 9/16.

Munćan, P. \& Živković, D. (2014). Menadžment ratarske proizvodnje. Beograd, Srbija: Poljoprivredni fakultet.

Nastić, L., Jeločnik, M. \& Subić, J. (2014). Analysis of calla lily and cucumber production in greenhouse. Ekonomika, 60 (4), 209-217.

Orović, D. (2017). Optimizacija poljoprivredne proizvodnje na porodičnim gazdinstvima u Topličkom okrugu. Nepublikovana doktorska disertacija, Beograd, Srbija: Poljoprivredni fakultet.

Radosavljević, M., Jovanović, R. \& Vančetović, J. (2005). Kvalitet zrna i mogućnosti korišćenja ZP hibrida kukuruza. PTEP 9(1-2), 12-14. 
RPKNS (2017). Navodnjavamo jedva tri odsto njiva, Regionalna privredna komora Novi Sad (RPKNS), web portal RPKNS: http://rpkns.com/navodnjavamo-jedva-tri-odstonjiva/

Sekulić, G., Dimović, D., Kalmar Krnajski Jović, Z. \& Todorović, N. (2012). Climate vulnerability assessment: Serbia, Belgrade, Serbia: Environmental improvement center: WWF for nature, web link: http://awsassets.panda.org/downloads/cva_srbija english.pdf

Šimunić, I., Pandžić, K., Ivančan Picek, Branka, Bogunović, M. \& Husnjak, S. (2007). Analiza manjka vode za razne biljne kulture. Agronomski glasnik, 69(3), $167-$ 177.

SORS (2018). Production indicators of silage maize, data base of the Statistical Office of the Republic of Serbia (SORS), Belgrade, Serbia.

Subić, J., Ivanović, L. \& Jeločnik, M. (2010). Uticaj podsticaja na pokrice varijabilnih troskova u proizvodnji ratarskih useva. Zbornik naučnih radova Instituta PKB Agroekonomik, 16(1-2), 251-264.

Subić, J. \& Jeločnik, M. (2016). Economic effects of new technologies application in vegetable production. In Subić, J., Tomić, D., Lovre, K. \& Ševarlić, M. (Eds.), Emerging technologies and the development of agriculture (pp. 15-35). Belgrade, Serbia: SAAE.

Terzić, D., Radosavljević, M., Milašinović Šeremešić, M, Pajić, Z. \& Todorović, G. (2012). ZP Hibridi kukuruza kao sirovina za proizvodnju silaže. Selekcija i semenarstvo, 18(2), 61-69.

Živić, M., Paunović, A., Madić, M., Knežević, D., Jelić, M. \& Bokan, N. (2016). Analiza proizvodnje kukuruza na području smedereva u periodu 2013-2015. godine. XXI Savetovanje o biotehnologiji, vol. 21(23), (117-122), Čačak, Srbija: Agronomski fakultet.

ZSV (2013). Cenovnik mašinskih usluga u poljoprivredi: 2013. Novi Sad, Srbija: Zadružni savez Vojvodine. 